Tér és Társadalom 23. évf. 2009/2. 45-68. p.

\title{
HAZAI KISTÉRSÉGEK INNOVÁCIÓS KÉPESSÉGÉNEK ELEMZÉSE
}

\author{
(Measuring the Innovation Performance \\ of Hungarian Subregions)
}

\section{BAJMÓCY ZOLTÁN - SZAKÁLNÉ KANÓ IZABELLA}

Kulcsszavak:

regionális innovációs rendszer innovációs képesség mérése kistérség

Napjaink térgazdasági folyamatait a tanulás-alapú gazdaság feltételrendszere formálja. E sajátos keretben a regionális változás egyik legfóbb hajtóereje az innovációk sorozatán keresztül megvalósuló technológiai változás. Így a regionális gazdaságtan egyik központi vizsgálati területévé vált a térségi innovációs képesség értelmezési és mérési lehetöségeinek vizsgálata, jóllehet az alacsony területi aggregációs szinteken folyó vizsgálatok számos módszertani problémát vetnek fel.

Jelen tanulmány célja a hazai kistérségek innovációs képességének elemzése és értékelése, melynek során a regionális innovációs rendszer koncepciót tekintjük kiindulási alapul. A kistérségek innovációs teljesítményét több dimenzió mentén és összesitve is rangsoroljuk, majd megadjuk a térségek csoportosítását, illerve vizsgáljuk az innovációs képesség térbeliségének szabályszerüségeit. A tanulmány utolsó fejezetében feltárjuk az alkalmazott megközelités korlátait, amellyel egyben az innováció-mérés metodikájának általános problémáira, és ily módon esetleges jövöbeni kutatási irányokra kívánunk rávilágitani.

\section{Bevezetés}

Napjaink ,tudás-alapú”, vagy „tanulás-alapư” gazdaságában az innovációs képesség és a térségek kívánatosnak vélt gazdasági folyamatai között szoros összefüggés áll fenn. A tanulás és innovációs képesség révén a régiók nehezen utánozható, egyedi eröforrásokra tesznek szert, amelyek segítik őket a területi versenyben történő helytállásban (Storper 1997; Lengyel 2003). A különböző területi egységek innovációs képességének (potenciáljának) megragadása ennél fogva élénken kutatott területté vált.

Bár az innováció-kutatás elsősorban nem regionális tudományi gyökerü (Solow 1957; Nelson-Winter 1982; Inzelt 1998; Marinov a-Phillimore 2003; Fagerberg 2005), a térbeliség mégis a kezdetektöl fogva szorosan kapcsolódik az innovációs folyamat és az innovációs képesség vizsgálatához (Hägerstrand 1952; MoulaertSekia 2003; Döry 2005; Lagendijk 2006).

A regionális tudomány egyrészt felhívta rá a figyelmet, hogy az innováció térbeli, helyhez kötött jelenség, amely nagymértékben függ olyan eröforrásoktól, amelyek térség-specifikusak, és amelyeket lehetetlen máshol reprodukálni (Storper 1997; Ács et al. 2000; Asheim-Gertler 2005). A szereplök térbeli elhelyezkedése, közelsége tehát alapvetöen fontos befolyásoló tényezője az innovációnak (Varga 2005). 
Bajmócy Zoltán - Szakálné Kanó Izabella : Hazai kistérségek innovációs képességének elemzése. Tér és Társadalom 23. évf. 2009/2. 45-68. p.

Másrészt feltárta, hogy a területi egységek innovációs képessége kapcsán a szubnacionális szinten történő vizsgálódás is alapvető fontosságú (Doloreux 2002; Lengyel-Rechnitzer 2004; Tödtling-Trippl 2005; Hollanders 2006), hiszen egy-egy ország innovációs potenciálja karakterisztikus térbeli struktúrával rendelkezhet, jelentős területi egyenlötlenségeket mutathat.

Jelen tanulmány ez utóbbi témakörhöz kapcsolódik a hazai innovációs képesség kistérségi szintú struktúrájának vizsgálata révén. A tanulmány első részében a térségi innovációs képesség értelmezési lehetőségeit és az ebből következő mérési megközelítéseit tekintjük át. Ezt követően ismertetjük kistérségi szinten folytatott vizsgálatunk módszertanát, majd elemezzük a felmérés révén nyert eredményeket.

Felmérésünk során több szempontot tartottunk szem elött. Egyrészt törekedtünk a területi egységek innovációs képességének mérésére irányuló legjelentősebb hazai és nemzetközi tanulmányok tanulságainak hasznosítására. Másrészt a kistérségi szinten történö elemzés végeredményeként egy összesített, és ezen felül az egyes részterületekre vonatkozó rangsort kívánunk megadni, amely a területi egységek teljesítményének összevetésén túl az egyes kistérségek relatíve erős, illetve gyenge pontjainak azonosítására is használható. Harmadrészt el kívánjuk végezni a hazai kistérségek innovációs képesség alapján történő csoportosítását. Negyedrészt pedig vizsgáljuk a kistérségi innovációs képesség térbeli struktúrájának szabályszerüségeit, a szomszédos kistérségek egymásra gyakorolt esetleges (túlcsorduló) hatását.

A tanulmány utolsó fejezetében az alkalmazott megközelítés korlátait elemezzük, amellyel néhány olyan kritikus pontra kíséreljük meg felhívni a figyelmet, amely a területi egységek innovációs képességének mérését célzó megközelítések általános problémája. Ezzel mintegy lehetséges jövőbeni kutatási irányokat is kínálunk. A tanulmány végén legfontosabb megállapításainkat összegezzük.

\section{A térségek innovációs képességének értelmezése és mérése}

Az innovációs folyamat és a térbeliség között szoros kapcsolat van. Erre utal Storper (1997) az ,innováció regionális világai” koncepcióval, és ezt bontják ki a különbözö területi innovációs modellek (TIM) is (Moulaert-Sekia 2003; Döry 2005; Lagendijk 2006). Az innovációnak tehát nem egyszerüen térbeli vetülete van, hanem a szereplők térbeli elhelyezkedése (eloszlása), illetve az adott regionális környezet endogén módon befolyásolja a kimenetelét (Varga 2005).

A regionális tudományban számos olyan koncepció (TIM) látott napvilágot, amely egyes térségek átlagon felüli innovációs teljesítményét (és ebből következően versenyképességét, sikerességét) kívánta magyarázni. Ezen elméletek alapvetően olyan jellegzetességek leírását adják, amelyekkel a sikeres térségek a többiekkel szemben rendelkeznek.

Részben ezt a hagyományt követi a regionális innovációs rendszerek (RIR) koncepciója, amely a TIM modellek közül az innovációs képesség magyarázata kapcsán különös jelentőségre tett szert. Ez a megközelítés nyilvánvalóan magán hordozza az 
Bajmócy Zoltán - Szakálné Kanó Izabella : Hazai kistérségek innovációs képességének elemzése. Tér és Társadalom 23. évf. 2009/2. 45-68. p.

TÉT XXIII. évf. 2009 『 2

Hazai kistérségek...

innováció rendszermodelljeinek jegyeit is a területiség hangsúlyozása mellett. A többi TIM modellhez képest a RIR koncepciónak jelentös elónye van a területi innovációs képesség értelmezési lehetösége szempontjából. A regionális innovációs rendszer koncepciója a (nemzeti innovációs rendszerhez hasonlón) ugyanis olyan elemekre vezeti vissza a régió innovációs teljesítményét, amelyek többé-kevésbé jelen vannak minden régióban, csak a teljesítményük és az elemek közti interakciók sürűsége különbözik. Ily módon a rendszer elemeit és a köztük lévö kapcsolatrendszert számba véve képet nyerhetünk a régió innovációs teljesítményéról (potenciáljáról).

Tödtling és Trippl (2005) a regionális innovációs rendszert egy nyitott szervezödésként írja le, melynek legfőbb elemei a „tudásteremtés és diffúzió" alrendszere, a „tudás-alkalmazás és -kiaknázás” alrendszere, a köztük lévő kapcsolatrendszer, valamint a mindezeket befolyásoló politikák. Cooke (2004) értelmezéséhez hasonlóan kiemelik a RIR társadalmi beágyazottságát. A RIR koncepció egyébként is erőteljes intézményi és evolucionista közgazdaságtani gyökerekkel bír, így az innovációs aktivitást befolyásoló tényezők között számba veszik a történetileg létrejött helyi intézményi és infrastrukturális környezetet, szabály- és kapcsolatrendszert, érdekérvényesítési mechanizmusokat.

Doloreux (2002) szintén elemek és kapcsolatok összességeként definiálja a regionális innovációs rendszert. A rendszer szereplöit négy alapvető kategóriába sorolja: cégek, intézmények, tudás-infrastruktúra és regionális innováció-politika. A rendszer mechanizmusai közül az interaktív tanulást, a tudástermelést, a közelséget és a társadalmi beágyazottságot emeli ki.

Dóry (2005) a regionális innovációs rendszer (és egyben potenciál) elmeinek megragadása kapcsán hat kategóriát hangsúlyoz: vállalkozások $\mathrm{K}+\mathrm{F}$ tevékenysége, vállalkozások közti kapcsolatok, innovációs szolgáltatások, technológiai kínálat, politikák és regionális környezet. Tehát ez a megközelítés is lényegében a korábbiakhoz hasonló tényezőket tartalmaz: a tudásteremtés és a kiaknázás rendszerét, valamint az ezt elösegítő háttérfeltételeket és politikákat.

Bár a RIR elemeinek rendszerezésében nem jelenik meg minden esetben explicit módon, a megközelítéshez mégis szorosan kapcsolódik azon háttértényezők szerepének a felismerése, amelyek lehetővé teszik a szereplók tanulási képességét és így a régió folytonos adaptációs készségét. $\mathrm{E}$ háttértényezők rendszerezésének széles körben használt sémája az úgynevezett "smart" (intelligens) infrastruktúra koncepciója (Malecki 1997; Stimson et al. 2006). A „smart” infrastruktúra fizikai és „puha” elemeket, valamint a (tudás-intenzív) ïzleti szolgáltatásokat öleli fel, és lényegében a térség vállalatainak tanulási képességét segíti elő.

A RIR és így a regionális innovációs képesség értelmezése kapcsán tehát bizonyos releváns elemek és a köztük lévő kapcsolatrendszer megragadása történik. A fellelhetö megközelítések gyakorlatilag a tudásteremtés, a tudáskiaknázás, az ezt lehetővé tevő, vagy ösztönző háttérfeltételek („smart” infrastruktúra) és az ezek közti komplex kapcsolatrendszer fontosságát emelik ki. Így lényegében a régiók innovációs képességének megragadása kapcsán ezen kategóriák számbavétele tünik célravezetönek. Az innovációs képesség megragadása tehát komplex mérési megközelítést igényel. 
Bajmócy Zoltán - Szakálné Kanó Izabella : Hazai kistérségek innovációs képességének elemzése. Tér és Társadalom 23. évf. 2009/2. 45-68. p.

Erre reflektál az innováció-mérés legtöbb gyakorlati kísérlete is. A szakirodalomban a területi egységek innovációs teljesitményének mérése kapcsán két markánsan elkülönülö megközelitéssel lehet találkozni. Az egyik (Európában hangsúlyosabbnak tủnö) iskola lényegében az innovációs rendszer elemeinek és a köztük lévö kapcsolatoknak a számszerüsítésére koncentrál. Ide tartoznak a „Europan Trend Chart on Innovation" keretében zajló vizsgálatok: a különböző Scoreboard jelentések, valamint ezek módszertani háttértanulmányai (Arundel-Hollanders 2005; Hollanders 2006; Kanerva et al. 2006; EIS 2007). Ebbe a csoportba sorolható be a legtöbb hazai kísérlet is: Csizmadia és Rechnitzer (2005) hazai nagyvárosokra irányuló felmérése, Kocziszky (2004) észak-magyarországi kistérségekre irányuló vizsgálata, vagy a rendszeresen megjelenő „Innováció a Nyugat-Dunántúlon” jelentések (Csizmadia et al. 2008). Ezen kísérletek erőssége mindenképpen az innováció komplex - a kutatás-fejlesztésen és annak outputjain túlmutató - értelmezésében, az innovációs rendszer elméletek eredményeinek alkalmazásában rejlik, gyengesége viszont az indikátorok kiválasztásának és esetleges súlyozásának problematikája.

Létezik ugyanakkor az innovációs képesség mérésének egy ettöl alapvetően eltérő megközelítése, ahol az innovációs képességet egy relevánsnak tartott mutatóra redukálják (illetőleg a többi mutatót csak áttételesen, ezen függỏ változóval való kapcsolat fényében veszik számításba). Az e családba tartozó innovációs felmérések talán legismertebb példáját Porter és Stern (2003) „Nemzeti Innovációs Kapacitás" indexe jelenti. Ök az országok innovációs képességének rangsorolásakor az Amerikai Szabadalmi Hivatalnál bejegyzett szabadalmak számát tekintik fủggỏ változónak. A Nemzeti Innovációs Kapacitás indexébe az alapján kerül be a többi indikátor, hogy milyen kapcsolat áll fent köztük és a fenti függő változó között (egy regressziós modellben).

A megközelítés erőssége az indikátorok kiválasztásának (magyarázóerejük alapján) és súlyozásának (a súlyt a regressziós együttható adja) modellen belüli viszonylagos objektivitása. Az indikátor magyarázóereje, illetve a regressziós együttható értéke egyértelmüen igazolja a vizsgálatban való szerepeltetését. Ám ugyanebböl ered a megközelités gyengesége is. Az egyetlen kiemelt függö változó kiválasztása ugyanis jelentős problémákat vet fel, tulajdonképpen egyenlővé teszi az innovációt és az invenciót. Ráadásul nehéz olyan függő változót találni, amely közel ugyanolyan jól lenne alkalmazható az országok (területi egységek) széles körében. E miatt például Porter és Stern munkája (jelentös idézettsége ellenére) a kritikák kereszttüzében áll.

Összességében úgy véljük, hogy bizonyos gyengeségeik ellenére a rendszermodelleken alapuló megközelítések jóval árnyaltabb képet képesek nyújtani a területi egységek innovációs képességéről és annak struktủrááról, továbbá lényegesen jobban tükrözik az innovációs folyamat természetét, képesek elszakadni az innováció lineáris megközelítésétől. Így jelen tanulmányban folytatott elemzésünk során mi is ezen szemlélet mellett köteleződünk el. 
Bajmócy Zoltán - Szakálné Kanó Izabella : Hazai kistérségek innovációs képességének elemzése.

Tér és Társadalom 23. évf. 2009/2. 45-68. p.

TÉT XXIII. évf. 2009 — 2

Hazai kistérségek ...

\section{Módszertan}

Vizsgálatunk során a hazai kistérségek innovációs kẻpességének összehasonlitását (rangsor felállítását) és a térségek csoportositását végeztük el, illetve elemeztük az innovációs képesség térbeli eloszlásának szabályszerűségét. Az elemzés alapegysége a 244/2003-as Kormányrendelet által definiált 168 hazai kistérség volt, az adatok a 2004. évre vonatkoznak (amennyiben az adott évre elérhetök voltak).

Az elemzés elsö lépése az alkalmazható indikátorkészlet kiválasztása és csoportosítása volt. Az indikátorok csoportjainak megalkotásánál, az innovációs rendszerek irodalmán alapuló mérési megközelítésekhez igazodva, egy „tipikus” regionális innovációs rendszer alkotóelemeinek megadására törekedtünk. Három kategóriát alakítottunk ki, amelyek mindegyike egy-egy alindex alapját képezi, ezek: a tudásteremtés, a tudás-kiaknázás, illetve a „smart” infrastruktúra (1. táblázat).

A tudásteremtés alindexének indikátorai a tudományos és technológiai tudás létrehozásának képességét mérik. Ezen mutatók használata széles körü, a legtöbb innovációs vizsgálat elemeit képezik. Meg kell említeni, hogy számos, az innovációt szúken értelmező megközelítés nem is lép túl az indikátorok ezen körén, a kutatásfejlesztést $(\mathrm{K}+\mathrm{F})$ az innovációval azonosítva, ezek alapján von le következtetéseket. Minthogy a $\mathrm{K}+\mathrm{F}$ nem feltétlenül vezet innovációhoz, és az innováció nem szükségszerủen feltételezi a $\mathrm{K}+\mathrm{F}$-et (OECD 2005), így mindenképpen szükséges további kategóriák kialakítása.

A tudás-kiaknázás alindex indikátorai alapvetően az innovációkat kiaknázni képes vállalati szektor jellemzöit kívánja megragadni, így egyrészt olyan indikátorokat használ, mint az export részesedés, vagy a külföldi müködő tőke jelenléte, másrészt a tudás-intenzív vállalati szektor részesedését jelzi.

A ,smart" infrastruktúra alindex azokat a tényezöket rendszerezi, amelyek a másik két alindex által mért teljesítmények müködtetéséhez szükségesek. Ez jelenti egyrészt a „tehetség” jelenlétét, illetve megtartásához szükséges feltételeket (pl. kulturálódás, szórakozás), a térség nem gazdasági értelemben vett ,nyitottságát" (pl. az odaérkezők száma), illetve az információs és kommunikációs technológiák kihasználását.

$\mathrm{Az}$ egyes alindexekhez tartozó konkrét indikátorok kiválasztásakor számos korábbi mérési kísérlet ${ }^{2}$ indikátorkészletét tekintettük át, figyelembe véve az egyes mutatók kistérségi szintủ elérhetőségét. Így végeredményként 28 indikátor alapján kezdtük meg a vizsgálatot.

Minthogy a vizsgálat célja az innovációs képesség megragadása, így igyekeztünk elkerülni olyan - több áttekintett elemzésben is szereplő (Kocziszky 2004; Csizmadia Rechnitzer 2005) - elemek szerepeltetését, amelyek a gazdaság általános jövedelemteremtő képességére utalnak, hiszen ez keveredést eredményez az innovációs aktivitásra való képesség, illetve az innováció révén nyert képességek megragadása között. 
Bajmócy Zoltán - Szakálné Kanó Izabella : Hazai kistérségek innovációs képességének elemzése. Tér és Társadalom 23. évf. 2009/2. 45-68. p.

\begin{tabular}{|c|c|c|c|}
\hline & $\begin{array}{l}1 . \text { TÁl } \\
\text { istérségi innovációs képess } \\
\text { dicator Set for Measuring S }\end{array}$ & $\begin{array}{l}\text { LÁZAT } \\
\text { g vizsgálat } \\
\text { bregional }\end{array}$ & $\begin{array}{l}\text { nak indikátorkészlete } \\
\text { nnovation Capacity) }\end{array}$ \\
\hline $\begin{array}{l}\text { Kategó- } \\
\text { ria }\end{array}$ & Megnevezés & Forrás & Megjegyzés \\
\hline \multirow{10}{*}{$\begin{array}{l}\text { Tudás- } \\
\text { teremtés }\end{array}$} & $\begin{array}{l}\text { K+F helyek száma } 100000 \text { lakosra } \\
(2004)\end{array}$ & $\begin{array}{l}\text { KSH Köz- } \\
\text { ponti adat- } \\
\text { bázis }\end{array}$ & \multirow{7}{*}{$\begin{array}{l}\text { Mind a számított, mind a tényleges } \\
\text { létszámadat figyelembevételét fontos- } \\
\text { nak tartottuk, hiszen egy kutató részidós } \\
\text { jelenlétéhez is kapcsolódhat tudásáram- } \\
\text { lás, ugyanakkor a stabil jelenlétet a } \\
\text { számitott létszám tükrözi jobban. } \\
\text { Az adat abszolút mutatójának szere- } \\
\text { peltetését is fontosnak tartottuk, hiszen } \\
\text { a jelentôs kutatói koncentráció önma- } \\
\text { gában is hatékonyságnöveló lehet. }\end{array}$} \\
\hline & $\begin{array}{l}\mathrm{K}+\mathrm{F} \text { helyek tudományos kutatói- } \\
\text { nak tényleges létszámadata } 1000 \\
\text { lakosra (2004) }\end{array}$ & $\begin{array}{l}\text { KSH Köz- } \\
\text { ponti adat- } \\
\text { bázis }\end{array}$ & \\
\hline & $\begin{array}{l}\mathrm{K}+\mathrm{F} \text { helyek tudományos kutatói- } \\
\text { nak számított létszámadata (2004) }\end{array}$ & $\begin{array}{l}\text { KSH Köz- } \\
\text { ponti adat- } \\
\text { bázis }\end{array}$ & \\
\hline & $\begin{array}{l}\text { K+F helyek tudományos kutatói- } \\
\text { nak számított létszámadata } 1000 \\
\text { lakosra (2004) }\end{array}$ & \multirow{4}{*}{$\begin{array}{l}\text { KSH Köz- } \\
\text { ponti adat- } \\
\text { bázis } \\
\text { MTA Köz- } \\
\text { testületi } \\
\text { Adatbázis } \\
\text { KSH Köz- } \\
\text { ponti adat- } \\
\text { bázis } \\
\text { KSH Köz- } \\
\text { ponti adat- } \\
\text { bázis }\end{array}$} & \\
\hline & $\begin{array}{l}\text { Köztestületi tagok száma } 10000 \\
\text { lakosra (2004) }\end{array}$ & & \\
\hline & $\begin{array}{l}\text { K+F helyek beruházásai } 1000 \\
\text { lakosra (2004) }\end{array}$ & & \\
\hline & $\begin{array}{l}\text { K+F helyek költségei } 1000 \text { lakosra } \\
(2004)\end{array}$ & & \\
\hline & $\mathrm{K}+\mathrm{F}$ helyek ráforditásai (2004) & $\begin{array}{l}\text { KSH Köz- } \\
\text { ponti adat- } \\
\text { bázis }\end{array}$ & $\begin{array}{l}\text { Az adat abszolút mutatójának szere- } \\
\text { peltetését is fontosnak tartottuk, } \\
\text { hiszen a ráfordítások jelentös kon- } \\
\text { centrációja önmagában is hatékony- } \\
\text { ságnöveló lehet. }\end{array}$ \\
\hline & $\begin{array}{l}\mathrm{K}+\mathrm{F} \text { helyek ráforditásai } 1000 \\
\text { lakosra (2004) }\end{array}$ & $\begin{array}{l}\text { KSH Köz- } \\
\text { ponti adat- } \\
\text { bázis } \\
\text { Magyar }\end{array}$ & \\
\hline & $\begin{array}{l}\text { A szabadalmak száma a kistérség- } \\
\text { ben } 2000 \text {-2004 közötti időszakban } \\
10000 \text { lakosra (2000-2004) }\end{array}$ & $\begin{array}{l}\text { Szabadalmi } \\
\text { Hivatal } \\
\text { PIPACS } \\
\text { WEB }\end{array}$ & \\
\hline \multirow{4}{*}{$\begin{array}{l}\text { Tudás- } \\
\text { kiaknázás }\end{array}$} & $\begin{array}{l}\text { Export értékesités a nettó árbevétel } \\
\text { \%-ában (2004) }\end{array}$ & APEH TA & $\begin{array}{l}\text { Az export értékesitést két eltérō vetitési } \\
\text { alappal is szerepeltetjük. Míg az árbevé- } \\
\text { telre történö vetítés a helyben folyó } \\
\text { termelés általános „versenyképessé- } \\
\text { gére" utal, addig a népességszámra } \\
\text { tơrténö vetités az export tevékenység } \\
\text { volumenére is utal. }\end{array}$ \\
\hline & $\begin{array}{l}\text { Export értékesítés nettó árbevétele } \\
\text { egy lakosra (2004) }\end{array}$ & APEH TA & \multirow{3}{*}{$\begin{array}{l}\text { A külföldi tulajdonlást és az átlagon } \\
\text { felüli innovációs aktivitást számos } \\
\text { elméleti és empirikus munka össze- } \\
\text { kapcsolja. } \\
\text { Az eljárás-innovációk igen gyakran } \\
\text { töke-elemekben testesúlnek meg. }\end{array}$} \\
\hline & $\begin{array}{l}\text { Külföldi érdekeltségú vállalkozá- } \\
\text { sok száma } 1000 \text { lakosra (2004) }\end{array}$ & $\begin{array}{l}\text { KSH Köz- } \\
\text { ponti adat- } \\
\text { bázis }\end{array}$ & \\
\hline & $\begin{array}{l}\text { Külföldi érdekeltségủ vállalkozá- } \\
\text { sok saját tökéje az összes saját tőke } \\
\text { \%-ában (2004) } \\
\text { Szellemi alkotások jövedelme } \\
1 \text { lakosra (2004) }\end{array}$ & $\begin{array}{l}\text { KSH Köz- } \\
\text { ponti adat- } \\
\text { bázis } \\
\text { APEH } \\
\text { SZJA }\end{array}$ & \\
\hline
\end{tabular}


Bajmócy Zoltán - Szakálné Kanó Izabella : Hazai kistérségek innovációs képességének elemzése.

Tér és Társadalom 23. évf. 2009/2. 45-68. p.

TÉT XXIII. évf. 2009 — 2

Hazai kistérségek ...

Tudás

kiaknázás

A 24 , valamint 29-34

alágazatokban múködő vállalkozá-

sok az összes vállalkozás \%-ában (2005)

A 64 és 72-73 alágazatokban mủködő vállalkozások az összes vállalkozás \%-ában (2005)

A 74 alágazatban mưködő vállalkozások az összes vállalkozás \%-ában (2005)

50 fơnél többet foglalkoztató tudás-intenzív vállalkozások száma (2005)

Az egyetemet, fơiskolát végzettek a foglalkoztatottakon belül (2001)

A vezető értelmiségi foglalkozásúak a foglalkoztatottakon belül (2001)

Nappali tagozatos hallgatók száma felsófokú oktatási intézményekben 1000 lakosra (2004)

Felsőoktatási intézményekben dolgozó oktatók száma (kihelyezett

"Smart" infrastruktagozatok szerint) 1000 lakosra (2004)

túra

ISDN vonalak száma 1000 lakosra (2004)

A nyilvános könyvtárak beiratkozott olvasóinak száma 1000 lakosra (2004)

Mozi látogatások száma 1000 lakosra (2004)

Múzeumi látogatók száma 1000 lakosra (2004)

Vendégek száma összesen a kereskedelmi szálláshelyeken 1000 lakosra (2004)
KSH Központi adatbázis

KSH Központi adatbázis

KSH Központi adatbázis

KSH Központi adatbázis
A felsorolt alágazatok a csúcstechnológiai feldolgozóipart takarják. Ez a besorolás szokványos a nemzetközi szakirodalomban. A társas és egyéni vállalkozások összesen.

A felsorolt alágazatok a ,csúcstechnológiai" szolgáltatásokat takarják. Ez a besorolás szokványos a nemzetközi szakirodalomban. A társas és egyéni vállalkozások összesen.

$\mathrm{Az}$ „Egyéb gazdasági szolgáltatások” alágazatot általában a tudás-intenzív iizleti szolgáltatások részének tekintik, így ebben a kategóriában szerepeltettük (az esetlegesen szóba jöhető "smart" infrastruktúra helyett).

A társas és egyéni vállalkozások összesen.

A vállalkozási szerkezetben elfoglalt helyen túl a tevékenységek gazdasági súlyára is utal. A 24, 29-34, 64, 72-74 tevékenységek összesen.

A társas és egyéni vállalkozások összesen.

Népszámlá- A „tehetség” jelenlétének és újuraterlási adatbá- melődésének indikátora.

zis

Népszámlá- A ,tehetség” jelenlétének és ủjraterlási adatbá- melôdésének indikátora.

zis

KSH Terü- A ,tehetség" jelenlétének és újraterleti Statisz- melödésének indikátora.

tikai Év-

könyv

KSH Területi

KSH Teriileti

KSH Területi

KSH Területi

A „tehetség" jelenlétének és újratermelödésének indikátora.

Az ICT infrastruktúra használatára utal.

A "tehetség" megtartásához szïikséges kulturális és szórakoztatási feltételek.

A ,tehetség" megtartásához sziukséges kulturális és szórakoztatási feltételek.

KSH Terü- A „tehetség” megtartásához szilkséleti ges kulturális és szórakoztatási feltételek.

KSH Terï- A térségbe áramló személyek által leti közvetített külső tudás, illetve értékek.

Forrảs: Saját szerkesztés.

Alapvetỏ dilemma volt az indikátorok abszolút, vagy relatív értékeinek szerepeltetése (illetve utóbbi esetben a megfelelö vetítési alap kiválasztása). Az egyes kistérségek adatainak összehasonlíthatósága végett általában valamilyen viszonyítási alap használata mellett döntöttünk, ez leggyakrabban a lakónépesség száma, a foglalkoztatottak száma, illetve a térség vállalkozásainak száma volt. Ugyanakkor az 
Bajmócy Zoltán - Szakálné Kanó Izabella : Hazai kistérségek innovációs képességének elemzése. Tér és Társadalom 23. évf. 2009/2. 45-68. p.

TÉT XXIII. évf. 2009 - 2

innovációs és $\mathrm{K}+\mathrm{F}$ tevékenység kapcsán a tevékenység volumene és eredményessége között igen szoros kapcsolat feltételezhetö: a koncentrálódó $\mathrm{K}+\mathrm{F}$ eredményessége várhatóan nagyobb, mintha ugyanannyi ráfordítást több térség között osztunk meg (Varga 2005). Éppen ezért néhány esetben nem relativizált mutatókkal dolgoztunk $(\mathrm{K}+\mathrm{F}$ helyek tudományos kutatónak létszámadata, $\mathrm{K}+\mathrm{F}$ helyek ráfordításai, 50 fönél többet foglalkoztató tudás-intenzív vállalkozások száma).

Az elemzés második lépésében a kistérségek innovációs képességének összevetése és ez alapján történö rangsorolása zajlott. Az egyes indexek kiszámításához (és így a rangsorok megadásához) a „European Innovation Scoreboard” (EIS) vizsgálatainak módszertanát vettük alapul - mind az Összesített Innovációs Index (SII), mind a Szolgáltató Szektor Innovációs Indexe (SSII) hasonló módon épül fel. Az ezek analógiájára kialakított „Kistérségi innovációs képesség” indexe (KIK index) a következő lépések során állt elö:

1) Az egyes indikátorok minimum és maximum értékeinek meghatározása. Szinte minden indikátorra jellemző volt, hogy egy-két kistérség adata (åltalában pozitív irányban) jelentősen kiugrott a magyarországi átlagértékhez viszonyítva. Kilógónak (outlier) tekintettünk egy adatot, ha az adatok szórásának több mint négyszeresével tért el az országos átlagértéktől. A legtöbb indikátor esetén 1-3 kilógó adat adódott. A kilógó adatokat nem vettük figyelembe a minimum és maximum értékek meghatározásakor (erre azért volt szükség, hogy a következő lépésben kialakuló skála ne legyen túlságosan koncentrált).

2) Az adatok átskálázása. Minden egyes adatból kivontuk az adott indikátor kapcsán nyert minimum értéket, és az így kapott értéket elosztottuk a maximum és minimum érték különbségével. Ily módon valamennyi átskálázott érték 0 és 1 közé esik. A kilógó adatok (az eltérés irányától függően) 0 vagy 1 értéket kaptak.

3) Az alindexek kialakitása. Az egyes alindexek a hozzájuk tartozó indikátorok értékeinek számtani átlagaként adódnak. Az indikátorok esetleges súlyozása megfontolható lépés lehet, ugyanakkor jelen vizsgálat során - az EIS módszertanának megfelelöen - az átláthatóságra helyeztük a hangsúlyt.

4) A KIK index kialakitása, és a sorrend felállitása. A KIK index a három alindex számtani átlaga. A Kistérségi Innovációs Képesség sorrendje a KIK index értékek csökkenö sorba állításából adódik. Az index (és alindex) értékek arányskálán mért értékek, így alkalmasak a más térségektől való távolság megragadására, az országos átlaggal történö összehasonlitásra.

Az egyes kistérségek KIK indexe tehát komplex módon, egy összetett indikátorrendszer alapján jellemzi a térség innovációs képességét. A megközelítés túlmutat a gyakran alkalmazott, $\mathrm{K}+\mathrm{F}-\mathrm{t}$ középpontba állitó elemzéseken: a tudásteremetés képessége mellett a tudás-kiaknázás alrendszerét és a mindezek müködtetéséhez szükséges „smart” infrastruktúra minöségét is jellemzi. A KIK index alapján jól teljesító térségek innovációs képessége tehát általában egy komplex, „több lábon álló” teljesítmény eredménye. Ezzel együtt előfordulhat, hogy egy-egy terület kiemelkedó érté- 
Bajmócy Zoltán - Szakálné Kanó Izabella : Hazai kistérségek innovációs képességének elemzése. Tér és Társadalom 23. évf. 2009/2. 45-68. p.

TÉT XXIII. évf. 2009 - 2

Hazai kistérségek...

kének köszönhetően sorolódik egy térség relatíve elöre a KIK index szerinti rangsorban, éppen ezért szükséges az egyes alindexek szerinti teljesítmény vizsgálata is.

$\mathrm{Az}$ elemzés harmadik szakasza a kistérségek lehetséges csoportositásának megadása innovációs képességük alapján. Ez hasonló módon történt, mint Csizmadia és Rechnitzer (2005) hazai nagyvárosok innovációs potenciálját vizsgáló tanulmányában. Az innovációs képesség mérésére megalkotott három alindex alapján történt a csoportképzés.

A három alindex standardizált értékeinek felhasználásával K-közép (K-means) klaszterelemzést végeztünk. Az elemzést három, négy és öt klaszter létrehozásával is elvégeztük. A csoportba való tartozás igen stabilnak mutatkozott, a klaszterek számának növelésével bizonyos csoportok továbbontása történt, de az egyes csoportok tagjai jelentősen nem változtak. A klaszter-középpontól mért távolság szóródása alapján a leginkább homogén klaszterek négy csoport kialakítása során adódtak, így ez tủnik a leginkább alátámasztott megoldásnak.

Az elemzés negyedik lépésében a kistérségi innovációs képesség térbeli szabályszerüségeit vizsgáltuk, vagyis, hogy a szomszédos területi egységek adatai egymáshoz hasonlóak-e. Lényegében a térbeli autokorrelációt mértük az egész országot tekintve a Moran-index, kistérségi szinten pedig a „Lokális Moran Index” segítségével.

A Moran által 1948-ban javasolt mérőszám, a Moran-index, a területi autokorrelációt méri hasonlóan az idősoros adatok autokorrelációjához (Moran 1950; Anselin 1988; Dusek 2004). Kiszámítása a következöképpen történik:

$$
I=\frac{M}{\sum_{i=1}^{M} \sum_{j=1}^{M} w_{i j}} \frac{\sum_{i=1}^{M} \sum_{j=1}^{M} x_{i} w_{i j} x_{j}}{\sum_{i=1}^{M} x_{i}^{2}} \text {, ahol }
$$

- $\quad M$ : a területi egységek száma, esetünkben 168 kistérség.

- $\quad x_{j}$ : a vizsgált adatértékek $\mathrm{j}$. területegységhez tartozó értéke, esetünkben az egyes alindexek, illetve a KIK index j. kistérséghez tartozó értéke.

- $\quad w_{i j}$ : a szomszédsági mátrix i. sorának j. eleme, értéke az i. és j. kistérségek szomszédossága esetén 1, különben 0 .

Mivel a területi egységek szomszédosságát sokféleképpen értelmezhetjük, ezért ennek megfelelően többféle szomszédossági mátrix is felírható. Mi a következőkben a bástya szomszédságot vettük alapul, azaz $w_{i j}$ akkor kapott 1 -es értéket, ha az i. és a j. kistérségnek van közös határszakasza, $w_{i j}$ értéke egyébként 0 .

Az, hogy az aktuális Moran I érték mekkora és milyen irányú autokorrelációt jelez, megállapítható a Monte Carlo módszerrel kiszámított pszeudo-szignifikancia szint nagyságából, illetve az I érték elöjeléből (2. táblázat). 
Bajmócy Zoltán - Szakálné Kanó Izabella : Hazai kistérségek innovációs képességének elemzése. Tér és Társadalom 23. évf. 2009/2. 45-68. p.

\section{TÁBLÁZAT \\ A Moran Index értelmezése \\ (The Interpretation of the Moran Index)}

\begin{tabular}{|c|c|c|}
\hline Szignifikancia & Index érték & Értelmezés \\
\hline $\mathrm{p}<0,05$ és & $\mathrm{I}<-0,00598$ & $\begin{array}{l}\text { erősen negatívan } \\
\text { autokorrelált }\end{array}$ \\
\hline $0,05 \leq \mathrm{p}<0,1$ és & I $<-0,00598$ & $\begin{array}{l}\text { gyengén negatívan } \\
\text { autokorrelált }\end{array}$ \\
\hline $0,1 \leq p$ & & $\begin{array}{l}\text { az autokorreláció nem } \\
\text { szignifikáns }\end{array}$ \\
\hline $0,05 \leq \mathrm{p}<0,1$ és & I $>-0,00598$ & $\begin{array}{l}\text { gyengén pozitívan } \\
\text { autokorrelált }\end{array}$ \\
\hline $\mathrm{p}<0,05$ és & I $>-0,00598$ & $\begin{array}{l}\text { erősen pozitívan } \\
\text { autokorrelált }\end{array}$ \\
\hline
\end{tabular}

Megjegyzés: „p" a pszeudo szignifikancia szintet jelöli. Az index értéket értelmezése során a -1/(M-1) hányadossal kell összevetni, amelynek értéke kistérségi adataink esetén: -0,00598

Forrás: Cliff-Ord (1981) alapján saját szerkesztés.

\section{TÁBLÁZAT}

A Lokális Moran Index értelmezése

(The Interpretation of the Local Moran Index)

\begin{tabular}{|c|c|c|}
\hline & Értelmezés & Feltételek \\
\hline $\begin{array}{l}\text { Magas - } \\
\text { Magas }\end{array}$ & $\begin{array}{l}\text { Mind a kistérség, mind szomszédjai } \\
\text { szignifikánsan átlag feletti index érték- } \\
\text { kel rendelkeznek. }\end{array}$ & $\begin{array}{l}\text { Local Moran I }>0 \\
\text { Standardizált mutató } \\
\text { érték }>0 \\
p<0,05\end{array}$ \\
\hline $\begin{array}{l}\text { Magas - } \\
\text { Alacsony }\end{array}$ & $\begin{array}{l}\text { A kistérség szignifikánsan átlag feletti, } \\
\text { míg szomszédjai szignifikánsan átlag } \\
\text { alatti index értékkel rendelkeznek. }\end{array}$ & $\begin{array}{l}\text { Local Moran } I>0 \\
\text { Standardizált mutató } \\
\text { érték }<0 \\
\mathrm{p}<0,05\end{array}$ \\
\hline- & Nincs szignifikáns összefüggés & $\mathrm{p}>0,05$ \\
\hline $\begin{array}{l}\text { Alacsony } \\
\text { - Magas }\end{array}$ & $\begin{array}{l}\text { A kistérség szignifikánsan átlag alatti, } \\
\text { míg szomszédjai szignifikánsan átlag } \\
\text { feletti index értékkel rendelkeznek. }\end{array}$ & $\begin{array}{l}\text { Local Moran } \mathrm{I}<0 \\
\text { Standardizált mutató } \\
\text { érték }>0 \\
p<0,05\end{array}$ \\
\hline $\begin{array}{l}\text { Alacsony } \\
\text { - Ala- } \\
\text { csony }\end{array}$ & $\begin{array}{l}\text { Mind a kistérség, mind szomszédjai } \\
\text { szignifikánsan átlag alatti index érték- } \\
\text { kel rendelkeznek. }\end{array}$ & $\begin{array}{l}\text { Local Moran } \mathrm{I}<0 \\
\text { Standardizált mutató } \\
\text { érték }<0 \\
\mathrm{p}<0,05\end{array}$ \\
\hline
\end{tabular}

Megiegyzés: A „p" a pszeudo-szignifikancia szintet jelöli.

Forrás: Saját szerkesztés.

A másik - a Moran Indexhez szorosan kapcsolódó - általunk kiszámolt mutatószám a Lokális Moran Index, amely a területi autokorreláltság lokális mérỏszámaként fogható fel. Ezek az értékek minden kistérségre külön kiszámolhatók. Ese- 
Bajmócy Zoltán - Szakálné Kanó Izabella : Hazai kistérségek innovációs képességének elemzése. Tér és Társadalom 23. évf. 2009/2. 45-68. p.

tünkben a vizsgált innovációs index aktuális kistérségbeli standardizált értékét összeszorozzuk a kistérség szomszédjainak együttes átlagos standardizált értékével. Ha az így kiszámolt Lokális Moran Index érték pozitiv, akkor az illető kistérség hasonló a szomszédjaihoz, ha az értéke negativ, akkor pedig azoktól eltérö. Ily módon az eredeti standardizált index értékkel összevetve a kistérségek öt kategóriába sorolhatók (3. táblázat).

\section{A hazai kistérségek innovációs képessége}

A hazai kistérségek innovációs képességét átfogóan a KIK index, illetve annak alindexei segítségével mutatjuk be, majd ezt követően térünk ki a kistérségek innovációs képesség alapján történő csoportositására, illetve a térbeli szabályszerüségek vizsgálatára.

A KIK index alapján tehetô egyik legáltalánosabb megállapitás, hogy az innovációs képesség tekintetében hatalmas területi egyenlötlenségek jellemzik Magyarországot (1. ábra). Csupán 14 olyan kistérség van, amely a 0,32-es KIK index értékkel jellemezhető magyarországi átlag felett teljesít. A többi 154 kistérség teljesítménye átlag alatti. Mindez arra utal, hogy az innovációs képesség térben hihetetlenül koncentráltan van jelen hazánkban.

\section{1. ÁBRA}

A kistérségi innovációs képesség (KIK) index szerinti elsö harminc kistérség (Top 30 Subregions Based on the Subregional Summary Index)

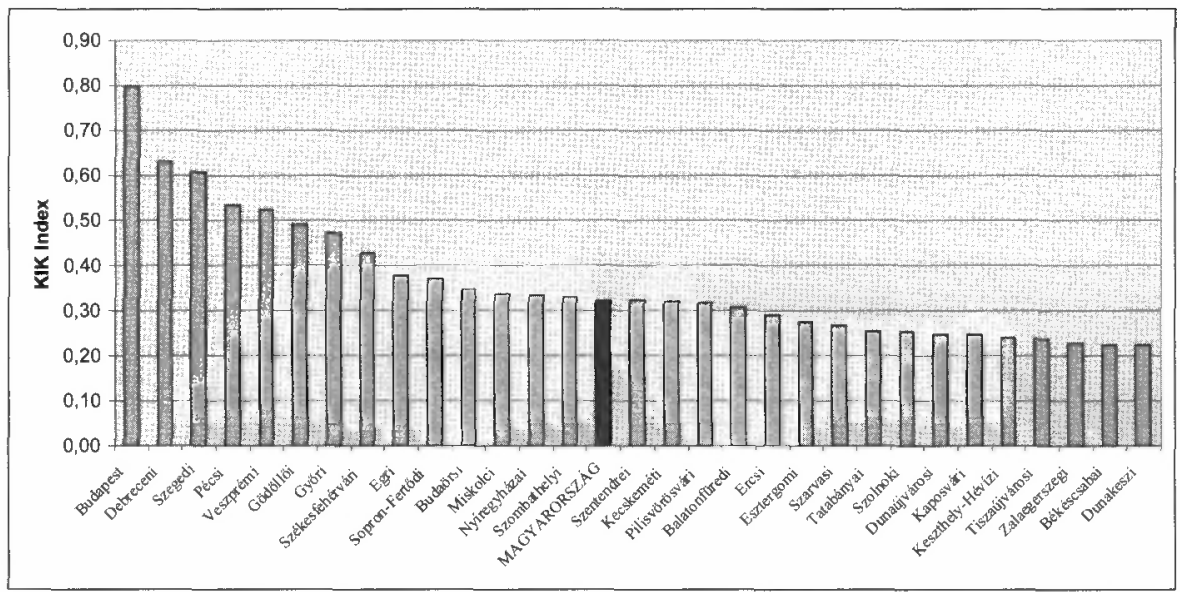

Forrás: Saját számítás.

Bár az első 30 kistérség közül 20 olyan, amely megyei jogú várossal rendelkezik, a sorrend mégsem teljesen a várakozásoknak megfelelö. Az első négy helyezett - ez megfelel a várakozásoknak - Budapest, a Debreceni, a Szegedi és a Pécsi kistérség, ezt követően azonban a Veszprémi és a Gödőllői kistérség következik. A régióközpontok közül a Miskolci kistérség csupán a 12. helyet szerezte meg. A megyei jogú 
Bajmócy Zoltán - Szakálné Kanó Izabella : Hazai kistérségek innovációs képességének elemzése. Tér és Társadalom 23. évf. 2009/2. 45-68. p.

várossal nem rendelkező kistérségek közül a Gödöllöi került be az első tízbe (6. helyen), míg további öt az elsỏ húszba: a Szentendrei, a Pilisvörösvári, a Balatonfüredi, az Ercsi és az Esztergomi kistérség. Érdemes még kiemelni, hogy három olyan kistérség, amely megyei jogú várossal rendelkezik, nem tudott bekerülni az első 30-ba. Ezek a Szekszárdi (41), a Salgótarjáni (43) és a Hódmezővásárhelyi (48) kistérség.

Budapest KIK index értéke $(0,80)$ - bár nem túlságosan - de kimagaslik a többi kistérséghez viszonyítva. Meg kell említeni, hogy Budapest a vizsgált 28 indikátor közül 10 esetben adott kilógó (outlier) értéket. Minthogy ez esetben automatikusan 1-es értéket kapott (bár teljesítménye ennél valójában magasabb), az index értéke lefelé torzít. Bár viszonylag sok kistérség mutatott outlier adatokat egy-egy indikátor kapcsán, nem volt más olyan kistérség, amely kettőnél több outlier adattal rendelkezett volna.

$\mathrm{Az}$ összesített eredményeket árnyalják az egyes alindexek szerinti rangsorok. Ezek alapján megmutatkozik, hogy a kistérségek képessége „féloldalas”, vagy „több lábon álló”. A tudásteremtés alindex szerinti rangsorban - csakúgy, mint a másik két alindex esetén is - Budapest áll az elsö helyen. A jelentősebb hazai egyetemek, illetve az MTA kutatóintézeti hálózatának területi eloszlása jól visszaköszön az alindex szerinti rangsorban. Ez természetesen annak a következménye, hogy a kutatás-fejlesztési tevékenység igen jelentős része ezen intézményekhez kötődik hazánkban (Magyarországon jóval magasabb a közfinanszírozás vállalati finanszírozáshoz viszonyított aránya a $\mathrm{K}+\mathrm{F}-\mathrm{ben}$, mint az európai átlag, jóllehet a GDP-hez viszonyítva ez már messze nem igaz).

A tudásteremtés területi koncentrációja még a KIK index alapján kapott sürüsödést is felülmúlja. Az országos átlag értéke igen alacsony $(0,25)$, és így is csupán 13 kistérség haladja azt meg. Már a rangsorban 28. kistérség értéke is 0,1 alatt van. Ennek megfelelően itt számos kisvárosi központtal bíró kistérség jó helyezése nem jár együtt jó teljesítménnyel. A kedvező relatív pozícióhoz kedvezötlen abszolút helyzet társul.

A tudás-kiaknázás alindexének országos átlagértéke az előbbinél jóval magasabb $(0,36)$, amelyet 18 kistérség múl felül (2. ábra). Az innovációs képesség ezen eleme kapcsán teljesen más sorrendet kapunk, mint a tudásteremtés esetén. Az innovációs centrumoknak tartott Szegedi, Pécsi és Debreceni kistérségek csupán a 15., 19. és 20. helyeket szerezték meg.

Érdekes, hogy több olyan kistérség, amely jeleskedik a külföldi működőtőkevonzásban és (részben ebböl következỏen) az exportban, a kategória más indikátorai kapcsán is (pl. tudás-intenzív szolgáltatások aránya) jól szerepel.

A tudásteremtés és a tudás-kiaknázás (akár nemzetközileg is értékesíthetö, magas hozzáadott értékú termékek elóállitásának) képessége hazánkban területileg elválik. A tudás-kiaknázás gyakran nem a helyben létrehozott tudást hasznosítja, a $\mathrm{K}+\mathrm{F}$ tevékenység eredménye pedig gazdaságilag kevéssé hasznosul. Csupán néhány térség mutatott stabil és eröteljes pozíciót mindkét terület kapcsán: Budapest mellett a Gödöllöi kistérséget lehet kiemelni. 
Bajmócy Zoltán - Szakálné Kanó Izabella : Hazai kistérségek innovációs képességének elemzése. Tér és Társadalom 23. évf. 2009/2. 45-68. p.

TÉT XXIII. évf. 2009 a 2

Hazai kistérségek ...

\section{2. ÁBRA}

A tudás-kiaknázás alindex szerinti elsö harminc kistérség

(Top 30 Subregions Based on the Knowledge-exploitation Sub-index)

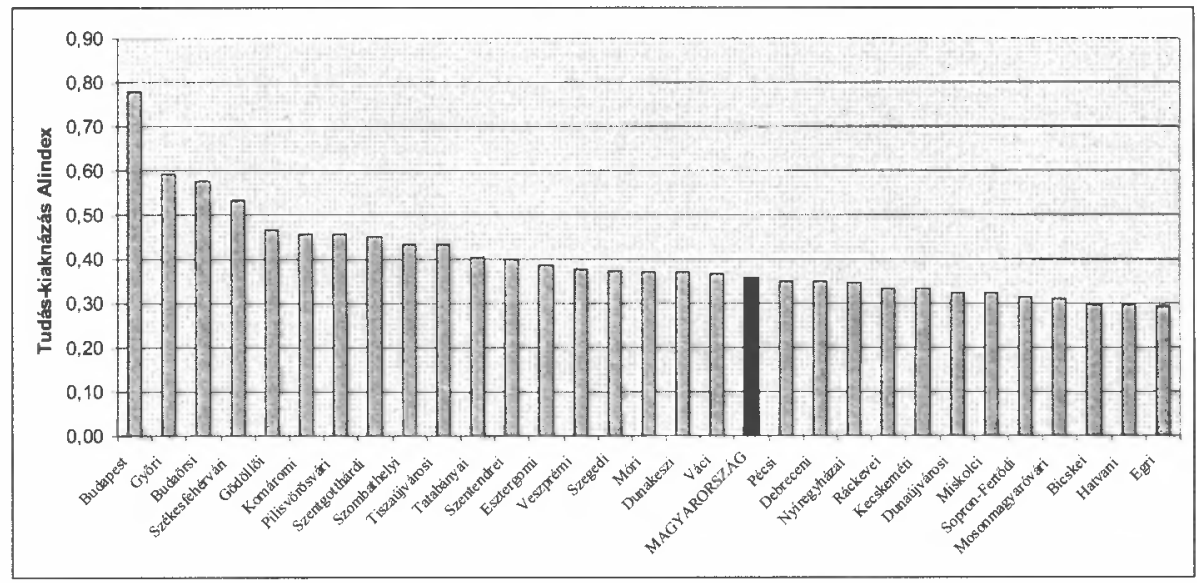

Forrás: Saját számítás.

$A$, smart" infrastruktúra alindex alapján kapott rangsor alapvetően a hazai városhálózat hierarchiảját adja vissza, bár kisebb eltérésekkel (4. ábra). A nagyvárosi központtal rendelkező kistérségeken túl elökelö helyezést tudott elérni néhány olyan kisebb lélekszámú kistérség, amely jelentős (kultur-)turisztikai célpont (Balatonfüredi vagy Keszthely-Hévízi kistérség). Ugyanakkor a rangsorbeli előkelö helyezéshez nem volt elegendő csupán egy vagy két indikátor kapcsán jól teljesíteni. A fenti kistérségek teljesítménye a kategória 5-6 indikátora mentén is átlag feletti. Az országos átlagérték a három közül ebben a kategóriában volt a legmagasabb $(0,37)$. Ezt az értéket 21 kistérség múlta felül. Érdemes megjegyezni, hogy míg a tudásteremtés kapcsán már a 28., addig itt csak a 147. helyezett kistérség értéke megy 0,1 alá.

A rangsorbeli eltérések az alindex értékek együttmozgását mérve is kiválóan viszszatükröződnek. A tudásteremtés és a tudáskiaknázás közötti kapcsolat jóval lazább, mint a tudásteremtés és a „smart" infrastruktúra értékek közötti (4. táblázat).

Igen lényeges megvizsgálni, hogy az innovációs képesség vajon visszatükrözödik-e a gazdasági teljesitményben mutatkozó különbségekben. Ezzel egyszersmind a vizsgálat eredményeit is lehet kontrollálni. Mind a KIK index, mind az egyes alindexek kapcsán közepes vagy erőteljes pozitív kapcsolat mutatható ki az egy lakosra jutó bruttó hozzáadott értékkel (GVA), illetve SZJA alapot képezö jövedelemmel. Kicsit lazább a kapcsolat a termelékenységi mutatóként felfogható egy foglalkoztatottra jutó GVA-val és adózás elötti eredménnyel (AEE), bár a tudáskiaknázás és a KIK index tekintetében ez is viszonylag eröteljes kapcsolatot takar.

A várakozásoknak megfelelően a tudás-kiaknázás alindexe mutatja a legszorosabb kapcsolatot a jövedelmi és termelékenységi mutatókkal, míg a tudásteremtés a leglazábbat. Ez egyben a „smart" infrastruktúra kategóriájának relevanciáját is bizonyítja. A korrelációs mátrix egyértelmüen bizonyítja az innovációs képesség és a gazdasági teljesítmény összefuiggését, ugyanakkor a kapcsolat erőssége arra is utal, hogy a kettő nem determinisztikusan következik egymásból. 
Bajmócy Zoltán - Szakálné Kanó Izabella : Hazai kistérségek innovációs képességének elemzése. Tér és Társadalom 23. évf. 2009/2. 45-68. p.

58 Bajmócy Zoltán-Szakálné Kanó Izabella

TÉT XXIII. évf. 2009

2

\section{TÁBLÁZAT}

$A^{\prime} K I K$ index és a szokásos jövedelmi mutatók korrelációs mátrixa

(Correlation Matrix of Certain Income Indicators and the Subregional Summary Index)

\begin{tabular}{|c|c|c|c|c|c|c|c|c|}
\hline & $\begin{array}{l}\text { Tudás- } \\
\text { teremtés }\end{array}$ & $\begin{array}{l}\text { Tudás- } \\
\text { kiakná- } \\
\text { zás }\end{array}$ & $\begin{array}{l}\text { "Smart" } \\
\text { infra- } \\
\text { struktura }\end{array}$ & $\begin{array}{l}\text { KIK } \\
\text { Index }\end{array}$ & $\begin{array}{c}\text { Egy } \\
\text { lakosra } \\
\text { jutó } \\
\text { GVA }\end{array}$ & $\begin{array}{c}\text { Egy } \\
\text { foglal- } \\
\text { koz- } \\
\text { tatottra } \\
\text { jutó } \\
\text { AEE } \\
\end{array}$ & $\begin{array}{c}\text { Egy } \\
\text { foglal- } \\
\text { koz- } \\
\text { tatottra } \\
\text { jutó } \\
\text { GVA }\end{array}$ & $\begin{array}{c}E g y \\
\text { lakosra } \\
\text { jutó } \\
\text { SZJA } \\
\text { alap }\end{array}$ \\
\hline Tudásteremtés & 1,000 & & & & & & & \\
\hline Tudás-kiaknázás & 0,593 & 1,000 & & & & & & \\
\hline „Smart” infrastruktúra & 0,736 & 0,611 & 1,000 & & & & & \\
\hline $\begin{array}{l}\text { KIK Index } \\
\text { Egy lakosra jutó }\end{array}$ & 0,904 & 0,825 & 0,892 & 1,000 & & & & \\
\hline $\begin{array}{l}\text { GVA } \\
\text { Egy foglalkoztatottra }\end{array}$ & 0,508 & 0,777 & 0,521 & 0,678 & 1,000 & & & \\
\hline $\begin{array}{l}\text { jutó AEE } \\
\text { Egy foglalkoztatottra }\end{array}$ & 0,359 & 0,605 & 0,291 & 0,471 & 0,773 & 1,000 & & \\
\hline $\begin{array}{l}\text { jutó GVA } \\
\text { Egy lakosra jutó }\end{array}$ & 0,483 & 0,748 & 0,499 & 0,650 & 0,992 & 0,773 & 1,000 & \\
\hline SZJA alap & 0,501 & 0,849 & 0,594 & 0,727 & 0,671 & 0,451 & 0,628 & 1,000 \\
\hline
\end{tabular}

Felvetődik továbbá, hogy az innovációs képesség miért mutat erőteljesebb kapcsolatot az egy lakosra jutó SZJA alap értékével, mint a munkatermelékenységi mutatókkal (hisz az innovációk eredményeként végsỏ soron termelékenységjavulást és kevésbé a jövedelmek növekedését várnánk). Ennek oka - véleményünk szerint -, hogy az innovációs képesség fenntartása nehezen választható el a magasan képzett, átlagosnál jobban fizetett munkakörökben dolgozó „tehetségek” jelenlététől.

Az eddigi elemzés is már egyértelmủen azt sejteti, hogy a hazai kistérségek innovációs képessége jelentősen szóródik. Néhány kistérség relatíve erős innovációs képességgel jellemezhetö, míg a kistérségek többségének innovációs teljesítménye gyenge. Ezen felül az egyes alindexek eltérö sorrendjei arra utalnak, hogy a relatíve erős innovációs teljesítmény is többféle módon eloállhat, a kistérségek e tekintetben is csoportokra bomlanak.

A három alindex standardizált értékei alapján elvégezett K-közép klaszterelemzés megerỏsítette azt, hogy a kistérségek innovációs képességük alapján csoportosíthatók. A klaszterképzỏ ismérvekkel való kapcsolat alapján a létrejött négy csoport viszonylag könnyen értelmezhetö (5. táblázat, 3. ábra). A legnagyobb elemszámú klaszter (129 kistérség) a gyenge innovációs képességgel rendelkezó kistérségeket tömöríti. Jellemzőjük, hogy mindhárom kategóriában gyengén teljesítenek. A klaszter homogén, a középponttól való (euklideszi) távolságok szórása 0,37. 
Bajmócy Zoltán - Szakálné Kanó Izabella : Hazai kistérségek innovációs képességének elemzése.

Tér és Társadalom 23. évf. 2009/2. 45-68. p.

TÉT XXIII. évf. 2009 『 2

Hazai kistérségek ...

59

5. TÁBLÁZAT
Klaszter-középpontok négy klaszter esetén
(Final Cluster Centres in Case of Four Clusters)

Forrás: Saját számítás.

Markánsan kirajzolódott egy kis elemszámú klaszter (5 kistérség), amelyet "féloldalas" innovációs képesség jellemez (3. ábra, 6. táblázat). Ezen kistérségek jó teljesítményt mutatnak a tudásteremtésben, a másik két szempont szerint azonban igen gyengék. Ez a klaszter is meglehetösen homogén, a klaszter-középponttól mért távolságok szórása 0,36 . Ugyanakkor a tudásteremtésben mért relatíve jó teljesítmény is több esetben gyenge abszolút teljesítményt takar, ugyanis a tudásteremtésben - mint ahogy azt korábban elemeztük - már az első harminc térség között is van olyan, amelynek index értéke 0,1 alatti.

28 kistérséget tömörít a közepes innovációs képességgel rendelkezők klasztere. Ezek innovációs képessége viszonylag egyenletes, és mindhárom kategóriában közepes értéket mutat. Ez a klaszter kevésbé homogén, a középponttól mért távolságok szórása 0,5. Azonban még így is jól elkülönül a többi klasztertől.

$\mathrm{Az}$ erős innovációs képességgel rendelkezők klasztere 6 kistérséget foglal magában. Ezek teljesítménye mindhárom területen kiugró. Ez a klaszter a legkevésbé homogén, a fenti módon adódó szórásérték 0,79 (Budapest nélkül azonban csak 0,44). Bár a klasztertagok mindhárom kategóriában jó teljesítményt mutatnak, a legerősebb értékekkel a tudásteremtés kapcsán rendelkeznek. A klasztertagok mindegyike egyetemváros.

Figyelemre méltó, hogy a tudásteremtésben kiugró kistérségek - Gödöllő kivételével - rendre jóval gyengébben teljesítenek a tudás-kiaknázás során (Gödöllőnek viszont a „smart” infrastruktúra értéke alacsony). A közepes innovációs képességgel rendelkezök közül a Györi és a Székesfehérvári kistérségek állnak legközelebb ahhoz, hogy átkerüljenek az erỏs innovációs képességủek közé. A régióközpontok közül a Miskolci kistérség azonban egyértelmủen a közepes képességủek csoportjába sorolódik. Jól látható, hogy a „féloldalas” kistérségeket a tudásteremtési képesség emeli ki, azonban a másik két szempont alapján szignifikánsan a „közepesek” klasztere alatt teljesítenek (5. táblázat). 
Bajmócy Zoltán - Szakálné Kanó Izabella : Hazai kistérségek innovációs képességének elemzése.

Tér és Társadalom 23. évf. 2009/2. 45-68. p.

\section{3. ÁBRA}

A hazai kistérségek csoportositása innovációs képességük alapján (Classification of Hungarian Subregions on the Basis of Their Innovation Capacity)

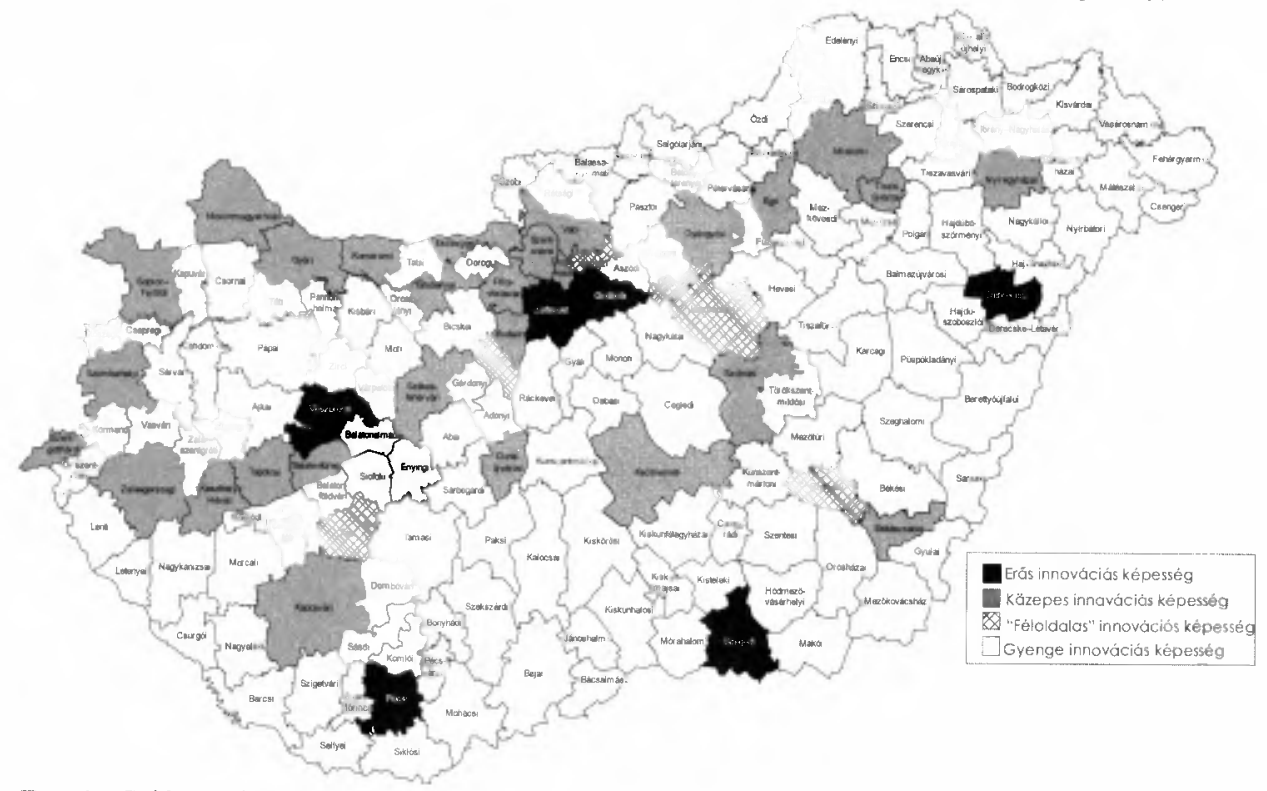

Forrás: Saját szerkesztés.

\section{TÁBLÁZAT}

Az egyes klaszterek tagjainak alindexenkénti teljesitménye (The Performance of Cluster-members with Respect to the Subindexes)

\begin{tabular}{llrrrr}
\hline Kistérség & $\begin{array}{c}\text { Tudásteremtés } \\
\text { alindex érték }\end{array}$ & $\begin{array}{c}\text { Tuaknás- } \\
\text { alindés } \\
\text { érték }\end{array}$ & $\begin{array}{c}\text { "Smart" } \\
\text { infra- } \\
\text { struktúra } \\
\text { alindex érték }\end{array}$ & $\begin{array}{c}\text { KIK index } \\
\text { érték }\end{array}$ \\
\hline $\begin{array}{c}\text { Erös innovációs } \\
\text { képesség }\end{array}$ & Budapest & $0,92(1)$ & $0,78(1)$ & $0,69(1)$ & $0,80(1)$ \\
& Debreceni & $0,89(2)$ & $0,35(20)$ & $0,65(3)$ & $0,63(2)$ \\
& Gödöllöi & $0,65(5)$ & $0,47(5)$ & $0,35(22)$ & $0,49(6)$ \\
& Pécsi & $0,58(6)$ & $0,35(19)$ & $0,66(2)$ & $0,53(4)$ \\
& Szegedi & $0,81(3)$ & $0,37(15)$ & $0,64(4)$ & $0,61(3)$ \\
& Veszprémi & $0,67(4)$ & $0,38(14)$ & $0,53(6)$ & $0,52(5)$ \\
\hline \multirow{2}{*}{ „Féloldalas ,,in- } & Ercsi & $0,52(7)$ & $0,25(44)$ & $0,10(141)$ & $0,29(19)$ \\
& Jászberényi & $0,17(20)$ & $0,25(42)$ & $0,20(55)$ & $0,21(35)$ \\
& Szarvasi & $0,41(8)$ & $0,13(102)$ & $0,25(37)$ & $0,27(21)$ \\
& Tabi & $0,14(23)$ & $0,29(32)$ & $0,14(101)$ & $0,19(40)$ \\
& Veresegyházi & $0,18(17)$ & $0,26(39)$ & $0,13(106)$ & $0,19(38)$ \\
\hline
\end{tabular}


Bajmócy Zoltán - Szakálné Kanó Izabella : Hazai kistérségek innovációs képességének elemzése.

Tér és Társadalom 23. évf. 2009/2. 45-68. p.

TÉT XXIII. évf. 2009 - 2

Hazai kistérségek...

61

\begin{tabular}{|c|c|c|c|c|c|}
\hline \multirow{28}{*}{$\begin{array}{l}\text { Közepes innová- } \\
\text { ciós képesség }\end{array}$} & Balatonfüredi & $0,23(14)$ & $0,20(60)$ & $0,49(8)$ & $0,31(18)$ \\
\hline & Békéscsabai & $0,03(63)$ & $0,24(48)$ & $0,41(17)$ & $0,22(29)$ \\
\hline & Budaörsi & 0,17 (19) & $0,58(3)$ & $0,30(30)$ & $0,35(11)$ \\
\hline & Dunakeszi & $0,08(31)$ & $0,37(17)$ & $0,22(48)$ & $0,22(30)$ \\
\hline & Dunaújvárosi & $0,12(26)$ & $0,32(24)$ & $0,30(29)$ & $0,25(24)$ \\
\hline & Egri & $0,27(12)$ & $0,29(30)$ & $0,56(5)$ & $0,38(9)$ \\
\hline & Esztergomi & $0,14(25)$ & $0,39(13)$ & $0,29(32)$ & $0,27(20)$ \\
\hline & Gyöngyösi & $0,11(27)$ & $0,23(51)$ & $0,30(28)$ & $0,21(33)$ \\
\hline & Gyôri & $0,32(10)$ & $0,59(2)$ & $0,50(7)$ & $0,47(7)$ \\
\hline & Kaposvári & $0,15(21)$ & $0,21(58)$ & $0,38(21)$ & $0,25(25)$ \\
\hline & Kecskeméti & $0,22(15)$ & $0,33(23)$ & $0,41(15)$ & $0,32(16)$ \\
\hline & Keszthely-Hévízi & $0,06(38)$ & $0,18(71)$ & $0,48(10)$ & $0,24(26)$ \\
\hline & Komáromi & $0,04(46)$ & $0,46(6)$ & $0,16(81)$ & $0,22(32)$ \\
\hline & Miskolci & $0,27(11)$ & $0,32(25)$ & $0,42(13)$ & $0,34(12)$ \\
\hline & Mosonmagyaróvári & $0,09(28)$ & $0,31(27)$ & $0,21(51)$ & $0,20(36)$ \\
\hline & Nyíregyházai & $0,18(18)$ & $0,35(21)$ & $0,47(11)$ & $0,33(13)$ \\
\hline & Pilisvörösvári & $0,19(16)$ & $0,46(7)$ & $0,30(27)$ & $0,32(17)$ \\
\hline & Sopron-Fertődi & $0,40(9)$ & $0,31(26)$ & $0,40(18)$ & $0,37(10)$ \\
\hline & Székesfehérvári & $0,26(13)$ & $0,53(4)$ & $0,48(9)$ & $0,43(8)$ \\
\hline & Szentendrei & $0,14(22)$ & $0,40(12)$ & $0,42(12)$ & $0,32(15)$ \\
\hline & Szentgotthárdi & $0,01(103)$ & $0,45(8)$ & $0,20(56)$ & $0,22(31)$ \\
\hline & Szolnoki & $0,08(32)$ & $0,28(35)$ & $0,41(16)$ & $0,25(23)$ \\
\hline & Szombathelyi & $0,14(24)$ & $0,43(9)$ & $0,41(14)$ & $0,33(14)$ \\
\hline & Tapolcai & $0,04(47)$ & $0,20(62)$ & $0,34(24)$ & $0,19(37)$ \\
\hline & Tatabányai & $0,07(35)$ & $0,40(11)$ & $0,29(33)$ & $0,25(22)$ \\
\hline & Tiszaújvárosi & $0,05(43)$ & $0,43(10)$ & $0,23(44)$ & $0,24(27)$ \\
\hline & Váci & $0,02(76)$ & 0,37 (I8) & $0,25(40)$ & $0,21(34)$ \\
\hline & Zalaegerszegi & $0,06(39)$ & $0,27(37)$ & $0,35(23)$ & $0,23(28)$ \\
\hline
\end{tabular}

Megjegyzés: Zárójelben az adott alindex, illetve KIK index helyezés található.

Forrás: Saját szerkesztés.

Megvizsgáltuk továbbá, hogy a kistérségi innovációs képesség térbelisége milyen szabályszerüségeket mutat, a szomszédos területi egységek adatai egymáshoz hasonlóak-e. Bizonyos esetekben a valós gazdasági térkapcsolatok ugyanis átléphetik a kistérségi határokat, így egyes kistérségek innovációs teljesítménye részben a szomszéd térség „túlcsorduló” hatásaiból származhat. Különösen nyilvánvaló ennek lehetősége a Budapestet övező relatíve jó innovációs képességgel rendelkező kistér- 
Bajmócy Zoltán - Szakálné Kanó Izabella : Hazai kistérségek innovációs képességének elemzése. Tér és Társadalom 23. évf. 2009/2. 45-68. p.

62 Bajmócy Zoltán-Szakálné Kanó Izabella

TÉT XXIII. évf. 2009

2

ségek gyürüje láttán. Egy ilyen elemzés tulajdonképpen ahhoz vihet közelebb, hogy mi volna egy hazai területi innovációs elemzés „ideális térfelosztása”.

\begin{tabular}{|c|c|c|c|}
\hline \multicolumn{4}{|c|}{$\begin{array}{l}\text { 7. TÁBLÁZAT } \\
\text { A globális Moran I-próba eredményei } \\
\text { (Results of the Global Moran I Test) }\end{array}$} \\
\hline Index elnevezése & $\begin{array}{c}\text { Moran I } \\
\text { érték }\end{array}$ & $P$ érték & Értelmezés \\
\hline Tudásteremtés & 0,0051 & 0,36 & $\begin{array}{c}\text { Nincs szignifikáns } \\
\text { autokorreláció* }\end{array}$ \\
\hline Tudás-kiaknázás & 0,3245 & 0,00 & $\begin{array}{l}\text { Erösen pozitívan } \\
\text { autokorrelált** }\end{array}$ \\
\hline $\begin{array}{l}\text { „Smart" infra- } \\
\text { struktúra }\end{array}$ & $-0,0269$ & 0,34 & $\begin{array}{l}\text { Nincs szignifikáns } \\
\text { autokorreláció* }\end{array}$ \\
\hline KIK index & 0,0523 & 0,11 & $\begin{array}{l}\text { Nincs szignifikáns } \\
\text { autokorreláció* }\end{array}$ \\
\hline
\end{tabular}

Megjegyzés: * 5\%-os szignifikancia szint mellett. A számítás a Geoda095i program segitségével történt.

Forrás: Saját számítás.

A KIK index és annak három alindexe közül csak egy, méghozzá a tudáskiaknázás alindex területi értékei között van erösen szignifikáns (pozitív) autokorreláció (7. táblázat). Ez azt jelenti, hogy a tudás-kiaknázás mértékét erősítő tényezők hatása túlmutat a kistérségi határokon.

Az ilyen kistérségi határokon túlmutató tényezők jelenléte a többi alindex és a KIK index esetében az egész országot tekintve nem szignifikáns. Budapest környezetében mégis található a kistérségeknek egy olyan összefüggő rendszere (Budapest, illetve a Szentendrei, Dunakeszi, Pilisvörösvári, Gödöllői, Budaörsi és Ráckevei kistérségek), amelyben mind a kistérségeknek, mind szomszédaiknak magas a KIK index értéke, vagyis a „,magas - magas” osztályba tartoznak.

Mindez arra utal, hogy az innovációs képesség tekintetében a fơváros és a környezö kistérségek szerves egységet alkotnak, a valós térkapcsolatok itt jelentősen átnyúlnak a kistérségi határokon. Az eredmények azt is sugallják, hogy Budapesten kívül nincs olyan jelentős innovációs központ az országban, amelynek kistérségi határokon átnyúló innovációs „kisugárzása” lenne.

A tudás-kiaknázás képességének pozitiv térbeli autokorrelációját két jelenség okozza: egyrészt a pozitív, másrészt a negatív (standardizált) alindex értékek térbeli sürüsödése (4. ábra). A magas Lokális Moran Index értékekkel bíró kistérségek eröteljes térbeli koncentrációja figyelhető meg Budapest környékén (,magas - magas” osztály).

Másrészt két további összefüggő terület látható a térképen: a Tiszántúl középső részén, illetve Északkelet-Magyarországon, ahol is mind a kistérség, mind a környezete alacsony tudás-kiaknázás alindex értékkel rendelkezik (,alacsony - alacsony „osztály). 
Bajmócy Zoltán - Szakálné Kanó Izabella : Hazai kistérségek innovációs képességének elemzése. Tér és Társadalom 23. évf. 2009/2. 45-68. p.

TÉT XXIII. évf. 2009 匹 2

Hazai kistérségek...

63

A tudás-kiaknázási képesség térbelisége tehát jellegzetes szabályszerủségeket mutat. Felvethetö egy kistérségi határokon átnyúló valódi regionális rendszer jelenlétének a lehetősége Közép-Magyarországon (legalábbis a tudás-kiaknázás tekintetében). Fontos eredmény ugyanakkor az is, hogy a másik két alindex esetén nincs szignifikáns autokorreláció. A „smart” infrastruktúra kapcsán ez kevésbé meglepő, hiszen ezen alindex értékei viszonylag jól igazodnak a település-hierarchiához (és így annak térbeli megjelenéséhez). A tudásteremtés alindex kapcsán viszont ez mindenképp arra utal, hogy kutatás-fejlesztési aktivitás (illetőleg a kutató-fejlesztő intézmények) hatása nem nyúlik túl saját kistérségükön.

\section{4. ÁBRA}

A Lokális Moran Index térbeli eloszlása a ,tudás-kiaknázás" alindexe kapcsán (Spatial Dispersion of Local Moran Index in Case of the Knowledge-exploitation Subindex)

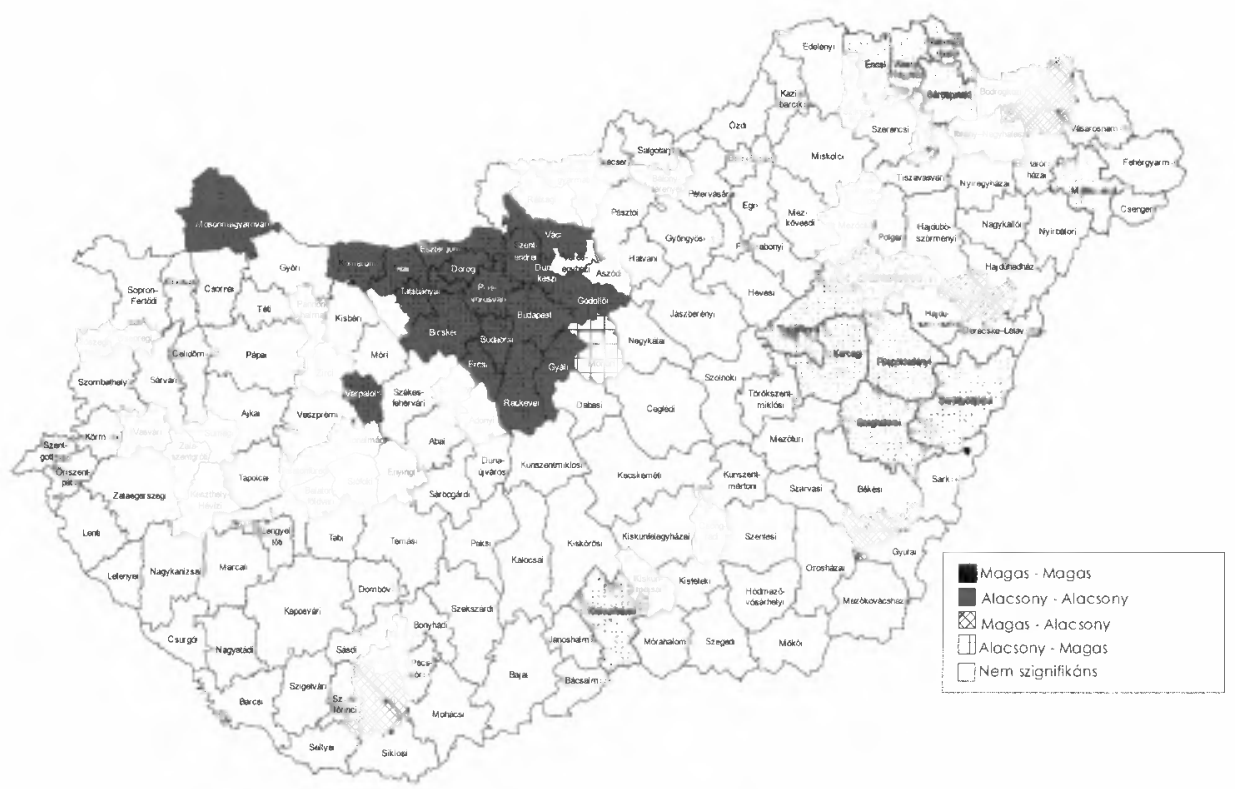

Megjegyzés: Az ábrán a Lokális Moran 1-próba értékei láthatók 5\%-os pszeudo-szignifikancia szint mellett, bástya-szomszédságot leképező szomszédossági mátrix használatával. Magas-magas viszony esetén mind a kistérségben, mind pedig a környezetében magas a tudás-kiaknázás alindex értéke. A számítás a Geoda095i program segítségével történt.

Forrás: Saját szerkesztés.

\section{Korlátok és jövőbeni kutatási irányok}

Az elemzésünk során alkalmazott módszer - egyebek mellett - számos olyan korláttal rendelkezik, amely az innováció-mérés általános metodikájában gyökerezik. A területi egységek innovációs képességének mérése és az ehhez kapcsolódó tudo- 
Bajmócy Zoltán - Szakálné Kanó Izabella : Hazai kistérségek innovációs képességének elemzése. Tér és Társadalom 23. évf. 2009/2. 45-68. p.

mányos viták szempontjából éppen ezért alapvetö fontosságúnak tartjuk ezen korlátok feltárását, és ily módon esetleges jövőbeni kutatási irányok megadását.

Az alkalmazott megközelités korlátjainak egy része a szubnacionális szintü elemzés következménye. Ez többé-kevésbé minden hasonló mérési kísérletet jellemez, de alapvetően nem kérdőjelezi meg a módszer relevanciáját. A területi adatok elérésének nehézségei általában a komplexitás bizonyos szintủ feladását teszik szükségessé. Az alacsonyabb területi aggregációs szinten folyó vizsgálatok a szükségesnél jóval kisebb mértékben képesek vállalati szintú innovációs adatok hasznosítására, avagy vállalati-szintủ adatok használata esetén csupán egy-két térségre korlátozzák a vizsgálat hatókörét (Hollanders 2006; Csizmadia et al. 2008). Ráadásul ebben az esetben az innovációs rendszerek elméletének egyik alapvetỏ eredménye kerül ki a vizsgálatok fókuszából (illetve kap kisebb fontosságot), nevezetesen a rendszer szereplői közötti kapcsolatok megragadása.

A regionális innovációs rendszerek irodalmának egy másik alapvető eredményét hagyják a megközelítések figyelmen kívül, amikor az esetenként gyökeresen eltérö jellegzetességekkel biró térségek innovációs képességét ugyanazon szempontok alapján mérik és hasonlítják össze. A regionális innovációs rendszer különböző típusai nem vonnak maguk után különbözö mérési megközelítést. Ugyanakkor például egy területileg beágyazott innovációs rendszer teljesítményéröl jóval többet mond az iparágon belüli és iparágak közötti tudásáramlások vizsgálata, mint mondjuk a $\mathrm{K}+\mathrm{F}$ tevékenység.

A megközelítés további korlátai jóval inkább paradigmatikus jellegüek. A területi egységek innovációs képességének mérése kapcsán meglehetős bizonytalanság észlelhető a tekintetben, hogy mit is mérjünk, mit is mérünk valójában. Vállalati szinten az innovációs aktivitás megragadása viszonylag egyértelmü (például a rendszeresen végrehajtott CIS felmérésekben ${ }^{3}$ egyértelmű az innovatív vállalat kritériuma). Ugyanakkor a mikroszintủ innovációk makrohatása gyakorlatilag bármi lehet (az innováció, az árbevétel vagy éppen a piaci részesedés nincs közvetlen összefüggésben). Talán pontosan emiatt valójában nem a térségek innovációs aktivitása, hanem az innováció egy före jutó GDP növeléséhez való hozzájárulásának képessége kerül számbavételre. Ez a megközelítés azonban mindenképpen prekoncepciókat hordoz magán: ex ante összeköti a gazdasági növekedés (a versenyképesség) és az innovációs képesség fogalmakat. Ennek tükrében azonban nem meglepö, ha az innovációs képesség és a gazdasági teljesítmény szoros kapcsolatot mutat.

Ez egyben magyarázhatja a különböző regionális innovációs rendszerek eltérő mérése iránti alacsony fogékonyságot is, hiszen a gazdasági növekedéshez való hozzájárulási képesség, mint „globális célfuiggvény” közös nevezöre hozza az eltérő térségeket az innovációs képesség mérése kapcsán.

A térségek teljesitményének összevetését célzó munkák általános sajátossága, hogy az innovációs képességet relativ módon (másokhoz viszonyitva) vizsgálják. Az évröl-évre közzétett rangsorok (mint például a „Scoreboard” jelentések) az átlaghoz viszonyított teljesítmény számbavételén alapulnak. Az átlagnak megfelelő teljesítmény-javulás tehát stagnálásként kerül interpretálásra (az átlagnál kisebb mértékủ 
Bajmócy Zoltán - Szakálné Kanó Izabella : Hazai kistérségek innovációs képességének elemzése.

Tér és Társadalom 23. évf. 2009/2. 45-68. p.

TÉT XXIII. évf. 2009 a

Hazai kistérségek ...

65

romlás pedig javulásként lenne feltüntetve). Úgy véljük, ez a szemlélet alapvetően abban gyökerezik, hogy (mint azt korábban kifejtettük) valójában az innovációs aktivitás gazdasági növekedéshez (versenyképességhez) történő hozzájárulási képességét mérik a vizsgálatok. A versenyképesség pedig relatív kategória. Szemlélete szerint gyakorlatilag teljesen mindegy, hogy milyen a teljesítményünk, ha az másokhoz és korábbi önmagunkhoz képest jó, illetve javul (Bajmócy 2007). Ez a megközelítés pedig a föáramú gazdaságtan és gazdaságpolitika általános szemléletéből ered, mely szerint a nagyobb növekedés (versenyképesség) jobb, mint a kisebb (gyakorlatilag minden körülmények között). Tulajdonképpen ez a szemlélet hatja át a lisszaboni stratégiát is, amely életre hívta a "Scoreboard" jelentéseket. Itt a fö kérdéssé az vált, hogy az egyes tagállamok mennyiben (és miben) maradnak el egymástól és föként az USA-tól és Japántól.

Mindennek azonban van egy másik (talán ennél is mélyebbre ható) gyökere. Ez pedig a schumpeteri hagyomány (bizonyos értelemben vett) negligálása az innováció-mérésben. A schumpeteri „teremtő pusztítás” folyamatosan lebontja a régi gazdasági struktúrát, és felváltja azt egy újjal (Schumpeter 1950). Ráadásul nem csak a gazdasági struktúra változik, hanem azzal „ko-evolúcióban” az infrastrukturális környezet, a társadalmi kapcsolatok, az érdekérvényesítési mechanizmusok, illetve a gazdaság és természeti környezet viszonya is (Polányi 1944; Kemp et al. 1998; Witt 2003). A teremtő pusztítás e folyamatának egyik következménye, hogy az innovációnak - legalábbis rövid távon - feltétlenül vannak vesztesei. Ráadásul joggal feltételezhetö, hogy a nyertesek és vesztesek térben is elkülönülhetnek.

A másik alapvető következmény, hogy az innovációs folyamat - minthogy egyszerre okoz változásokat a gazdaságban, társadalomban és természeti környezetben - nagyfokú és folyamatos alkalmazkodást tesz az érintettektől szükségessé. Ez esetben viszont egyáltalán nem mellékes a változás üteme, azaz adott esetben a túl gyors változás (a kiemelkedỏ innovációs teljesítmény) akár katasztrofális gazdasági és környezeti hatásokat is eredményezhet.

Mindez azt vonja maga után, hogy a területi egységek innovációs képességének mérése kapcsán célszerủnek tủnik egy eddigieknél jóval komplexebb megközelítés alkalmazása: a társadalmi és környezeti hatások beintegrálása a mérésbe, illetve a változás „vállalható” ütemének megragadása.

\section{Összegzés}

A tanulmány során a hazai kistérségek innovációs képességének komplex, több indikátoron alapuló elemzését végeztük el, melynek során a regionális innovációs rendszerek koncepcióját tekintettük kiindulási alapul. A három kategóriába sorolt komplex indikátor-rendszer nyomán az elemzés túlmutat a kutatás-fejlesztést hangsúlyozó megközelítésen. A tudásteremtés mellett a tudás-kiaknázás és mindezek fenntartásához szükséges „,smart” infrastruktúra teljesítményét is számba vettük. 
Bajmócy Zoltán - Szakálné Kanó Izabella : Hazai kistérségek innovációs képességének elemzése. Tér és Társadalom 23. évf. 2009/2. 45-68. p.

Az eredmények alapján kiviláglik, hogy az innovációs képesség területi megoszlása hatalmas egyenlötlenségekkel terhelt Magyarországon. Az innovációs képesség néhány kistérségben összpontosul. Az erös innovációs képességgel rendelkezö néhány kistérség mellett a közepes innovációs képességüek csoportja sem túlságosan bö. Ez utóbbi jellemzően a nagyobb lélekszámú központokkal rendelkező kistérségeket öleli fel, bár ez alól mutatkozik néhány kivétel.

Igen lényeges, hogy a tudásteremtés és a tudás-kiaknázás térben elkülönül hazánkban. Igen csekély azon kistérségek száma, amely mindkét kategóriában élenjáró. A tudásteremtés hatása jellemzően nem mutat túl a kistérségi határokon, és helyi tudás-kiaknázással is csak ritkán párosul. A tudás-kiaknázási képesség ugyanakkor jellegzetes térbeli mintákat mutat. Budapest környékén e tekintetben számos kistérség kapcsolódik össze szervesen.

A tanulmány végén rámutattunk, hogy a területi egységek innovációs képességének mérésére irányuló megközelítések számos olyan korláttal bírnak, amelyek felvetik az általánosan bevett sémák újragondolásának szükségességét. Célszerünek tűnik az innováció-mérés során a gazdasági jelzőszámokon túl az innováció indukálta társadalmi és környezeti változások egyidejü megragadása is, hiszen csak a három dimenzió együttes vizsgálata adhatna valós alapot arra (a folyó gyakorlatra), hogy az innovációs képességet és a térségek kívánatosnak vélt változási irányát összekapcsoljuk.

\section{Jegyzetek}

${ }^{1}$ Meg kell ugyanakkor jegyezni, hogy egyes szerzök (a többi TIM modellhez hasonlóan) olyan jegyek összességeként értelmezik a RIR-t, amely kiemel bizonyos térségeket a területi verseny során. Azaz szerintük a rendszer elemeinek puszta megléte még nem elegendő ahhoz, hogy RIR-röl beszéljünk, ehhez az alrendszerek közti tényleges regionális (helyi) kapcsolatrendszerek megléte is szükséges (Asheim Coenen 2005).

${ }^{2}$ A European Innovation Scoreboard (EIS) Összesített Innovációs Indexének (EIS 2007), a European Trend Chart on Innovation Szolgáltató Szektor Innovációs Indexének (Kanerva et al. 2006), az EXIS Összesített Indexének (Arundel-Hollanders 2005), Florida-Tingali (2004) Európai Kreativitási Indexének, a European Regional Innovation Scoreboard (Hollanders 2006) indexének indikátorkészletét, továbbá Csizmadia és Rechnitzer (2005) hazai nagyvárosok innovációs potenciáljának vizsgálata során alkalmazott indikátorait és Kocziszkynak (2004) az Észak-magyarországi régió kistérségei innovációs potenciáljának vizsgálatakor alkalmazott indikátorkészletét.

${ }^{3}$ CIS: Community Innovation Survey. Az Eurostat által koordinált rendszeres, vállalati megkérdezésen alapuló adatgyújtés, melynek módszertana megfelel az Oslo Kézikönyv (OECD 2005) ajánlásainak.

\section{Irodalom}

Ács, J.Z.-de la Mothe, J.-Paquet, G. (2000) Regional Innovation: In Search of an Enabling Strategy. Ács, J.Z. (ed.) Regional Innovation, Knowledge and Global Change. Pinter, London-New York. 37-49. o.

Anselin, L. (1988) Spatial Econometrics: Methods and Models. Kluwer, Dordrecht.

Arundel, A.-Hollanders, H. (2005) EXIS: An Exploratory Approach to Innovation Scoreboards. European Trend Chart on Innovation, European Commission, Maastricht.

Asheim, B.T.-Coenen, L. (2005) Knowledge Bases and Regional Innovation Systems: Comparing Nordic Clusters, - Research Policy. 34, 1173-1190, o. 
Bajmócy Zoltán - Szakálné Kanó Izabella : Hazai kistérségek innovációs képességének elemzése. Tér és Társadalom 23. évf. 2009/2. 45-68. p.

Asheim, B.T.-Gertler, M.C. (2005) The Geography of Innovation: Regional Innovation Systems. Fagerberg, J.-Mowery, D.C.-Nelson, R.R. (eds.) The Oxford Handbook of Innovation. Oxford University Press, Oxford-New York. 291-317. o.

Bajmócy Z. (2007) A technológiai inkubáció elmélete és alkalmazási lehetóségei hazánk elmaradott térségeiben. Doktori Értekezés. SZTE Gazdaságtudományi Kar, Szeged.

Cliff, A.D.--Ord, J.K. (1981) Spatial Processes: Models and Applications. Pion, London.

Cooke, P. (2004) Regional Innovation Systems - An Evolutionary Approach. - Cooke, P.-Heidenreich, M.Braczyk, H.J. (eds.) Regional Innovation Systems. The Role of Governance in a Globalized World. Routledge, London-New York. 1-18. o.

Csizmadia Z.-Rechnitzer J. (2005) A magyar városhálózat innovációs potenciálja. - Grosz A.Rechnitzer J. (szerk.) Régiók és nagyvárosok innovációs potenciálja Magyarországon. MTA RKK, Pécs-Györ. 147-180. o.

Csizmadia Z.-Erdős F.-Grosz A.-Smahó M.-Tilinger A. (2008) Innováció a Nyugat-Dunántúlon, 2008. MTA RKK, Pécs-Györ.

Doloreux, D. (2002) What should we know about regional systems of innovation. - Technology in Society. 24. 243-263. o.

Döry T. (2005) Regionális innováció-politika. Kihivások az Európai Unióban és Magyarországon. Dialóg Campus, Budapest-Pécs.

Dusek T. (2004) A területi elemzések alapjai. Regionális Tudományi Tanulmányok 10. ELTE Regionális Földrajzi Tanszék - MTA - ELTE Regionális Tudományi Kutatócsoport, Budapest.

EIS (2007) European Innovation Scoreboard 2007. Comparative analysis of innovation performance. Inno Metrics, Bruxelles.

Fagerberg, J. (2005) Innovation. A Guide to the Literature. - Fagerberg, J.-Mowery, D.C.-Nelson, R.R. (eds.) The Oxford Handbook of Innovation. Oxford University Press, Oxford-New York. 1-26. o.

Florida, R.-Tingali, I. (2004) Europe in the Creative Age. DEMOS. http://www.demos.co.uk/ publications/creativeeurope Letöltve: 2008. 04. 10.

Hägerstrand, T. (1952) The Propagation of Innovation Waves. Lund Studies in Geography, Gleerup.

Hollanders, H. (2006) European Regional Innovation Scoreboard. European Trend Chart on Innovation, Maastricht.

Inzelt A. (1998) Bevezetés az innováció közgazdaságtana és a technomenedzsment fogalomkörébe. Inzelt A. (szerk.) Bevezetés az innovációmenedzsmentbe. Az innovációmenedzsment és a technológiamenedzsment kapcsolata. Müszaki Könyvkiadó, Budapest. 19-32. o.

Kanerva, M.-Hollanders, H.-Arundel, A. (2006) Can We Measure and Compare Innovation in Services. 2006 Trend Chart Report. European Trend Chart on Innovation, Luxemburg.

Kemp, R.-Schot, J.-Hoogma, R. (1998) Regime Shifts to Sustainability Through Processes of Niche Formation: The Approach of Strategic Niche Management. - Technology Analysis \& Strategic Management. 2. 175-195. o.

Kocziszky Gy. (2004) Az Észak-Magyarországi régió innovációs potenciáljának vizsgálata. - ÉszakMagyarországi Stratégiai Füzetek. 1. 5-39. o.

Lagendijk, A. (2006) Learning from Conceptual Flow in Regional Studies: Framing Present Debates, Unbracketing Past Debates. - Regional Studies. 4. 385-399. o.

Lengyel I. (2003) Verseny és területi fejlódés. Térségek versenyképessége Magyarországon. JATEPress, Szeged.

Lengyel I.-Rechnitzer J. (2004) Regionális Gazdaságtan. Dialóg Campus, Budapest-Pécs.

Malecki, E.J. (1997) Technology and Economic Development: The Dynamics of Local, Regional and National Competitiveness. Longman, Edinburgh.

Marinova, D.-Phillimore, J. (2003) Models of Innovation. - Shavinina, L.V. (ed.) The International Handbook on Innovation. Elsevier Science, Oxford. 44-53. o.

Moran, P.A.P. (1950) Notes on continous stochastic phenomena. - Biometrika. 1-2. 17-23. o.

Moualert, F.-Sekia, F. (2003) Territorial Innovation Models: A Critical Survey. - Regional Studies. 3. 289-302. o.

Nelson, R.R.-Winter, S.G. (1982) An Evolutionary Theory of Economic Change. Belknap Harvard, MA, Cambridge - London.

OECD (2005) Oslo Manual. Guidelines for Collecting and Interpreting Innovation Data. Third edition, OECD, Paris.

Polányi, K. (1944) The Great Transformation: The Political and Economic Origins of Our Times. Rinehart, New York.

Porter, M.E.-Stern, S. (2003) The impact of location on global innovation: Findings from the National Innovative Capacity Index. - The Global Competitiveness Report 2002-2003. WEF. 227-252. o. 
Bajmócy Zoltán - Szakálné Kanó Izabella : Hazai kistérségek innovációs képességének elemzése. Tér és Társadalom 23. évf. 2009/2. 45-68. p.

Schumpeter, J. (1950) Capitalism, Socialism and Democracy. Third edition. Harper and Row, New York.

Solow, R.M. (1957) Technical Change and the Aggregate Production Function. - Review of Economic and Statistics. 39. 312-320. o.

Stimson, R.J.-Stough, R.R.-Roberts, B.H. (2006) Regional Economic Development. Analysis and Planning Strategy. Second edition. Springer, Heidelberg.

Storper, M. (1997) The Regional World. Territorial Development in a Global Economy. The Guilford Press, New York-London.

Tödtling, F.-Trippl, M. (2005) One size fit all? Towards a differentiated regional innovation policy approach. - Research Policy. 34. 1203-1209. o.

Varga A. (2005) Agglomeráció, technológiai haladás és gazdasági növekedés: A $K+F$ térszerkezet makrogazdasági hatásainak vizsgálata. MTA Doktora Értekezés, Pécs.

Witt, U. (2003) Economic Policy Making in an Evolutionary Perspective. - Journal of Evolutionary Economics. 13. 77-94. o.

\section{MEASURING THE INNOVATION PERFORMANCE OF HUNGARIAN SUBREGIONS}

\section{ZOLTÁN BAJMÓCY - IZABELLA SZAKÁLNÉ KANÓ}

Today's spatial economic processes are heavily influenced by the conditions of the learningbased economy. In this peculiar framework one of the main drivers of regional change is technological change occurring through the sequence of innovations. Therefore, the interpretation and measurement of territorial innovation capacity has become one of the main fields of interest in regional economics, however the analyses conducted in lower levels of territorial aggregation raise several methodological problems.

Present paper aims to analyse and evaluate the innovation capacity of the Hungarian LAU-1 subregions on the theoretical basis of the regional systems of innovation. We rank the innovation capacity of the subregions along distinct dimensions and also complexly, then we carry out the classification of the subregions, and we also analyse the spatial regularities of the innovation capacity. In the last chapter we attempt to shed light on the limitations of the applied approach in order to discuss the problems of the usual methods of innovationmeasurement and thus to provide possible future research directions. 